\title{
Impact of Altitude and Land Use Type on Some Physical and Chemical Properties of Acidic Soils in Tsegede Highlands, Northern Ethiopia
}

\author{
Abreha Kidanemariam ${ }^{1}$, Heluf Gebrekidan ${ }^{1}$, Tekalign Mamo $^{2}$, Kibebew Kibret ${ }^{1}$ \\ ${ }^{1}$ School of Natural Resource Management and Environmental Science, Haramaya University, Haramaya, Ethiopia; ${ }^{2}$ Ministry of \\ Agriculture and Rural Development, Addis Ababa, Ethiopia. \\ Email: abrehakidanemariam@gmail.com
}

Received June $5^{\text {th }}, 2012$; revised July $8^{\text {th }}, 2012$; accepted July $21^{\text {st }}, 2012$

\begin{abstract}
A study was conducted in the Tsegede highlands of Tigray Region, northern Ethiopia to determine the changes in some physical and chemical attributes across three adjacent acidic soil sites with different elevation and three land use types. Analytical results of the collected surface layer soil samples showed significant $(\mathrm{P} \leq 0.05)$ correlation of soil bulk density, $\mathrm{OM}$ and total $\mathrm{N}$ with elevation. In the lower elevation site (Indaslasie), soil OM content declined by about 43 and $52 \%$ compared with that of the two higher elevation sites (Cheguarcudo and Indamariam), respectively. Soil pH, exchangeable acidity, exchangeable $\mathrm{Al}, \mathrm{OM}$, total $\mathrm{N}$ and available phosphorus also exhibited significant $(\mathrm{P} \leq 0.05)$ disparity across the three land use types of the area. Soils of the forest land were less acidic by 0.43 and $0.68 \mathrm{pH}$ units than the cultivated and grazing lands, respectively. The soil OM content of the cultivated land was significantly lower by about 25 and $35 \%$ than the grazing and forest land soils, respectively. Available soil P status was low and showed significant correlations with $\mathrm{pH}\left(\mathrm{r}=0.65^{* *}\right)$, exchangeable acidity $\left(\mathrm{r}=-0.58^{*}\right)$ and $\mathrm{Al}\left(\mathrm{r}=-0.53^{*}\right)$. In general, the study results revealed altitude did not impose any significant effect in aggravating soil acidity whereas land use type affected significantly not only soil acidity but also the important soil fertility related parameters such as $\mathrm{OM}$, total $\mathrm{N}$ and available $\mathrm{P}$ contents. Therefore, it can be suggested that besides to the usual acid soil management and/or reclamation practices, introducing proper land use management systems are of paramount importance.
\end{abstract}

Keywords: Acidic Soil; Altitude Variability; Highland; Land Use Type

\section{Introduction}

Soil acidity is one of the most important soil factors which influence plant growth and ultimately limit crop production and profitability. More than $30 \%$ of the total cultivated land area of Ethiopia is believed to be affected by soil acidity of differing magnitude [1,2]. Accordingly, together with declining levels of soil fertility under no or only limited use of external nutrient inputs, soil acidity is becoming one of the serious soil degradation problems that hamper sustainable agricultural development mainly in the highlands of Ethiopia [3,4].

Soil acidification is a natural process mainly conditioned by naturally acid parent rocks and leaching of base forming ions attributed to high precipitation [5]. Although soil acidity is naturally occurring in some areas, in many others cases, agricultural practices have accelerated the process of soil acidification [6,7]. Normally, the indication for high soil acidification in soil solution is associated with the presence of $\mathrm{pH}$ levels lower than 5.5 and high exchangeable acidity [8]. The existence of high exchangeable acidity in a soil usually indicates the occurrence of exchangeable hydrogen $(\mathrm{H})$, exchangeable aluminum ( $\mathrm{Al})$ as either free $\mathrm{Al}^{3+}$ ion or partially neutralized Al-hydroxy compounds such as $\mathrm{Al}(\mathrm{OH})^{2+}$ or $\mathrm{Al}(\mathrm{OH})_{2}^{+}$, and weak organic acid ions held at the colloidal surfaces of the soil $[9,10]$. Although the availability of plant nutrients such as phosphorus $(\mathrm{P})$ and calcium (Ca) can be limiting at low soil $\mathrm{pH}$ [11], $\mathrm{Al}$ toxicity is probably the foremost plant growth and productivity limiting factor in acid soils [12-14].

Soil $\mathrm{pH}$ may also control biotic factors such as the activity and biomass composition of fungi, bacteria and other micro-flora and fauna in the soils of both natural (forests and grasslands) and agricultural lands $[15,16]$. This in turn affects the rates of microbial mediated biochemical reactions including oxidation of organic residues, mineralization of organic nutrients and symbiotic molecular nitrogen $\left(\mathrm{N}_{2}\right)$ fixation in legume plant root nodules. 
Altitude is often employed to study the effects of climatic variables on soil organic matter dynamics and the ratio of organic carbon to nitrogen $(\mathrm{N})$ which determines the level of decomposition of the organic matter and mineralization of organic $\mathrm{N}$ [17-20]. The change in altitudinal gradients influences soil organic matter by controlling soil water balance, soil erosion, geologic deposition processes, species and biomass production of the native vegetation and cultivated plants [21]. Moreover, there are reports that indicate the change in land use particularly from forest land to agriculturally managed (grazing and cultivated) lands in the different highland zones of the country are among the major causes of the removal of fertile surface soils and deterioration of the physical, chemical and biological fertility and productivity levels of the soils [22-25]. Thus, assessing the influences of altitude variability and land use dynamics induced changes in soil physical and chemical characteristics is essential for addressing the issue of agroecosystem transformation and the low fertility and productivity levels of the acidic soils in the country at large and at the study areas in particular.

In line with remaining high rainfall received highlands of the country, severe soil acidity problem has also been re- ported recently in the highland areas of the Tsegede Dis- trict of Tigray Region located in the northern highlands of Ethiopia [26]. The limitation of knowledge and detail information on the characteristic features, areal extent and magnitude of the acidic and potentially acidic soils of the Tsegede highlands which lead to their proper delineation and mapping prompted this study so as to develop sustainable acid soil management strategy. Furthermore, studies with regard to the effects of elevation and land use changes on the physicochemical properties of such acidic soils are scanty. Hence, the objective of this study was to determine the spatial variability of some soil physical and chemical properties over elevation and land use types in the Tsegede highlands of highlands, Western Zone of Tigray Region in northern Ethiopia.

\section{Materials and Methods}

\subsection{Site Characteristics}

Tsegede District is located in the Western Zone of Tigray Region between $13^{\circ} 14^{\prime} 21^{\prime \prime}$ and $13^{\circ} 44^{\prime} 46^{\prime \prime}$ north latitude and $36^{\circ} 27^{\prime} 44^{\prime \prime}$ and $37^{\circ} 45^{\prime} 5^{\prime \prime}$ east longitude within the tropics (Figure 1). It is characterized by diverse physiogeographic features with high and rugged mountains, flat topped plateaux, deep gorges, incised river valleys and rolling plains. The altitudinal variation ranges from 500 meters around Dansha to 3000 meters above sea level (masl) at Cheguarcudo. Tsegede District has two major agro-ecological zones; hot to warm moist lowlands (M1) and tepid to cool moist mid-highlands (M2) [27]. As per the Tsegede Water Resource Development Office [28], the Tsegede highlands, where this study was carried out, receive a mean annual rainfall of about $2224 \mathrm{~mm}$ and usually rainfall starts around the end of March and ends at early November with the highest amount of rainfall falling in August. The mean annual temperature of the area is $13.2^{\circ} \mathrm{C}$ and ranged from $7.8^{\circ} \mathrm{C}$ to $18.6^{\circ} \mathrm{C}$. The dominant soil type in the Tsegede highlands is mainly Humic Cambisols [29]. The major geologic parent materials of the area are principally basic volcanic rocks (pyroxene-olivine basalt) [30]. Mixed crop-livestock production is the dominant farming system of the area. Out of the total area of the District, $71.45 \%$ is covered by crop land, $19.81 \%$ is grazing land, $6.54 \%$ is under forest vegetation and about $2.2 \%$ is estimated to be area covered by rock outcrops and settlement.

\subsection{Sampling Protocol}

Three adjacent acidic soil sites of Tsegede highlands namely; Cheguarcudo, Indamariam and Indaslasie, found at the same agroecology (tepid to cool moist mid-highlands) with different elevation were selected. Thirty six composite soil samples were collected from the surface layer ( 0 - $30 \mathrm{~cm}$ depth) soils of each site. Elevation of the sampling points from the Cheguarcudo, Indamariam and Indaslasie sites varied from 2854 to 2965,2845 to 2902 and 2332 to 2778 meters above sea level, respectively. The 36 composite surface soil samples were yet again composed of, on an average, 22, 8 and 6 samples from three land use types (cultivated, grazing and forest) of each site, respectively, which is proportional to their area coverage. Each composite soil sample was prepared from 20 subsamples taken by scraping away the surface litter of each randomly marked sampling point and inserting the auger up to a depth of $30 \mathrm{~cm}$. All the subsamples were collected in a bucket and were thoroughly mixed. Finally, about $1 \mathrm{~kg}$ of soil sample was taken using quartering method from the composite bulk soil in the bucket to a polyethylene bag and labeled with the necessary information.

A total of twenty seven undisturbed soil samples were also collected by taking three samples from each land use type of each site using the core method. Weight and volume of the tin bottom and top of the cylindrical core sampler were first recorded and labeled. A smooth undisturbed vertical surface at each sampling point was prepared by scraping away the surface litter and the core sampler was pressed into the soil sufficiently to fill the inner core without inducing compression. After careful removal of the undisturbed soil cores with trim ends of acceptable soil cores flush with the end of the cylinder were collected. The GPS readings for the coordinates and 

Tsegede Highlands, Northern Ethiopia

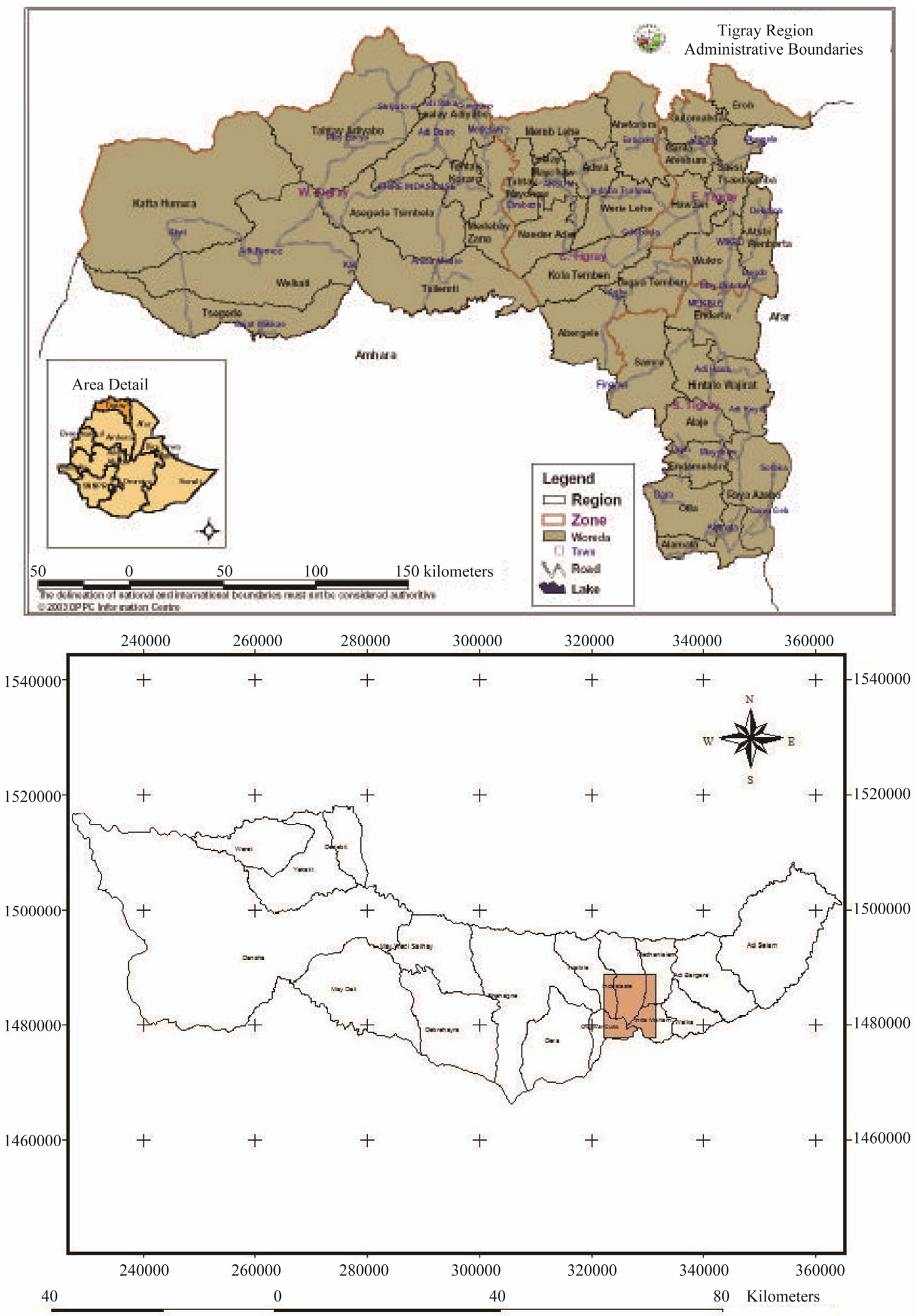

Figure 1. Map of the Tsegede district and location of the study areas. 
altitude as well as the land use types were also recorded simultaneously for each sampling points.

\subsection{Laboratory Analysis}

The composite surface $(0-30 \mathrm{~cm}$ depth) soil samples collected were air-dried and ground to pass through a 2 $\mathrm{mm}$ sieve. One hundred eight composite soil samples were analyzed for $\mathrm{pH}$ and exchangeable acidity; 31 samples (from selected land uses) for soil texture, organic matter, total nitrogen, available $\mathrm{P}$ and exchangeable Al. Twenty seven undisturbed soil samples were analyzed for bulk density. Determination of moisture correction factor (MCF) was done on the bases of Hesse [31]. Particle size distribution (soil texture) was determined by the Bouyoucos hydrometer method [32] and bulk density was estimated using the core sampling method [33]. Soil $\mathrm{pH}(1: 2.5)$ soil to water ratio was measured using glass electrode $\mathrm{pH}$ meter as described by Peech [34]. Exchangeable acidity and exchangeable $\mathrm{Al}$ were analyzed following the procedures outlined by Sumner [35] and Pansu et al. [36], respectively. Organic carbon (OC) was determined by the wet acid dichromate digestion method and soil organic matter (OM) was calculated by multiplying percent $\mathrm{OC}$ by a factor of 1.724 [37] whereas total nitrogen was analyzed by the semi-micro Kjeldahl digestion followed by ammonium distillation and titrimetric determinations [38]. Analysis of available phosphorus was conducted following the procedure of the Bray I method of extraction [39] using ascorbic acid as a reductant in the presence of antimony and determined spectrophotometrically.

\subsection{Statistical Analyses}

An analysis of variance was used to test differences in soil physical and chemical properties across the different elevation sites and land use types. For statistically dif- ferent parameters ( $\mathrm{P} \leq 0.05)$, means were separated using the Least Significant Difference (LSD) comparison test. Correlation analyses were also carried out to detect functional relationships among key soil variables. Data analyses were done using a statistical software package [40]. Soil acidity map was developed by subjecting the GPS readings and $\mathrm{pH}$ data to the Arc View GIS 10 and the degree of acidity which is expressed as a $\mathrm{pH}$ value was categorized on the bases of the rating suggested by Dek$\operatorname{ker}[41]$.

\section{Results and Discussion}

\subsection{Elevation and Its Relationship with Some Physical and Chemical Properties of Acidic Soils}

Elevation showed statistically significant correlation with soil bulk density, $\mathrm{OM}$ and total $\mathrm{N}$ whereas soil $\mathrm{pH}$, exchangeable acidity, exchangeable acidity $\mathrm{Al}$, texture and available P did not (Table 1).

\subsubsection{Soil Bulk Density}

The overall mean value of surface soil bulk density of the area was low (Table 2) as compared to the usual bulk density of mineral soils suggested by Brady and Weil [42]. It had significant correlation and variation with elevation (Tables 1 and 3). Relatively higher average soil bulk density was observed in the soils of lower elevation site (Indaslasie) as compared to those of higher elevation sites (Indamariam and cheguarcudo) (Table 3).

The low overall soil bulk density of the area and the relatively higher bulk density soils of the lower elevation site (Indaslasie) might be attributed to the existence of high OM accumulation in the whole area in general and the relatively lower OM accumulation in the lower elevation site. In connection with this, the overall bulk density showed significant negative correlation with soil OM

Table 1. Correlation coefficient and probability values of surface layer $(0-30 \mathrm{~cm})$ soil pH, exchangeable acidity, exchangeable $\mathrm{Al}$, sand, silt and clay fractions, $\mathrm{OM}$, total $\mathrm{N}$ and available $\mathrm{P}$ with elevation.

\begin{tabular}{ccc}
\hline Soil property & Correlation coefficient $(\mathrm{r})$ & P-values \\
\hline $\mathrm{pH}$ & 0.07 & 0.7262 \\
Exchangeable acidity & 0.06 & 0.7531 \\
Exchangeable Al & 0.15 & 0.4075 \\
Bulk density & -0.42 & 0.0353 \\
Sand & 0.37 & 0.0578 \\
Silt & -0.28 & 0.1338 \\
Clay & -0.12 & 0.5352 \\
OM & 0.52 & 0.0028 \\
Total N & 0.36 & 0.0441 \\
Available P & 0.23 & 0.1969 \\
\hline
\end{tabular}


Table 2. Statistics of the overall surface layer $(0-30 \mathrm{~cm})$ soil $\mathrm{pH}$, exchangeable acidity, exchangeable Al, sand, silt and clay fractions, $\mathrm{OM}$, total $\mathbf{N}$ and available $\mathbf{P}$.

\begin{tabular}{lccccc}
\hline Soil property $^{*}$ & No. samples & Mean & Std Dev & Minimum & Maximum \\
\hline Elevation (masl) & 108 & 2813 & 145.0 & 2329 & 2965 \\
$\mathrm{pH}$ & 108 & 5.08 & 0.470 & 4.140 & 6.330 \\
Exch. acidity $\left(\mathrm{cmol}_{\mathrm{C}} \cdot \mathrm{kg}^{-1}\right)$ & 108 & 1.95 & 1.824 & 0.000 & 6.560 \\
Exch. Al $\left(\mathrm{cmol}_{\mathrm{C}} \cdot \mathrm{kg}^{-1}\right)$ & 31 & 3.50 & 1.378 & 0.560 & 5.520 \\
Bulk density $\left({\left.\mathrm{g} \cdot \mathrm{cm}^{-1}\right)}^{\text {Sand }(\%)}\right.$ & 27 & 1.00 & 0.170 & 0.741 & 1.305 \\
Silt (\%) & 31 & 47.22 & 8.679 & 31.280 & 65.280 \\
Clay (\%) & 31 & 39.75 & 7.153 & 24.720 & 52.720 \\
Organic matter $(\%)$ & 31 & 13.03 & 5.535 & 4.000 & 24.000 \\
Total N (\%) & 31 & 8.63 & 4.209 & 1.009 & 21.684 \\
Available P $\left(\mathrm{mg} \cdot \mathrm{kg}^{-1}\right)$ & 31 & 0.38 & 0.178 & 0.078 & 0.946 \\
\hline
\end{tabular}

"masl = Meters above sea level; Exch. = Exchangeable; Std Dev = Standard deviation.

Table 3. Soil pH, bulk density, $\mathrm{OM}$ and total $\mathrm{N}(\mathrm{Means} \pm \mathrm{SE}$ ) status across three different elevation sites.

\begin{tabular}{ccccc}
\hline Site name & Altitude $(\mathrm{m})$ & Bulk density $\left(\mathrm{g} \cdot \mathrm{cm}^{-3}\right)$ & Organic matter $(\%)$ & Total N $(\%)$ \\
\hline Cheguarcudo & $2910 \pm 28.27^{\mathrm{b}}$ & $0.93 \mathrm{~b} \pm 0.05^{\mathrm{ab}}$ & $11.95 \pm 0.92^{\mathrm{a}}$ & $0.45 \pm 0.04^{\mathrm{a}}$ \\
Indamariam & $2877 \pm 27.2^{\mathrm{b}}$ & $0.88 \mathrm{~b} \pm 0.07^{\mathrm{b}}$ & $9.92 \pm 0.92^{\mathrm{a}}$ & $0.46 \pm 0.04^{\mathrm{a}}$ \\
Indaslasie & $2606 \pm 27.49^{\mathrm{a}}$ & $1.14 \pm 0.05^{\mathrm{a}}$ & $5.11 \pm 0.92^{\mathrm{b}}$ & $0.26 \pm 0.04^{\mathrm{b}}$ \\
\hline
\end{tabular}

Mean values within columns followed by the same letter(s) are not significantly different at $\mathrm{P} \leq 0.05$.

(Figure 2). Thus, the soils with high OM accumulation are higher in percent pore space regardless of the amount of soil particles in the soil and results in lower bulk density whereas the soils with lower OM are lower in percent pore space and results in higher bulk density. Similar report by Sanjay et al., [43] also pointed out that the lower bulk density at top altitudes are good indication of soils that has occupied coarser structure of organic matter and enriches the spaces by soil organic carbon.

\subsubsection{Soil Organic Matter and Total $\mathbf{N}$}

As per the soil OM classification suggested by Benton Jones [44], the average value of surface soil organic matter content (Table 2) was very high. It was also observed to be affected significantly by elevation (Tables 1 and 3). Soil OM content of the lower elevation site (Indaslasie) was found to be reduced by about $43 \%$ and $52 \%$ than the two high elevation (Cheguracudo and Indamariam) sites, respectively (Table 3). Likewise, mean value of total $\mathrm{N}$ was high (Table 2) as per the classifcation rate suggested by Landon [45] and showed significant disparity with elevation gradient (Tables 1 and 3).

The accumulation of relatively high soil OM in all the sites in general could be ascribed to the presence of high precipitation which promotes plant growth, cooler temperature and high soil acidity of the area which could decrease the rate of decomposition and mineralization of soil OM. Reports have also revealed that soil OM accumulation increases with increasing precipitation and decreases with increasing temperature [46]. Likewise, soil $\mathrm{pH}$ may control biotic factors, such as the biomass composition of fungi and bacteria in both forests $[16,47,48]$ and agricultural $[15,49]$ soils. However, the relatively lower accumulation of soil OM in Indaslasie site might be attributed to its significant positive correlation with altitude difference (Figure 3). Although the information with regard to the annul temperature of each experimental sites is not available, usually lower altitudes areas are having higher temperature than the areas with high altitude. Thus, this relatively high temperature in the Indaslasie site might enhance the soil OM decomposition and mineralization thereby decreases its accumulation in the area. The change in altitudinal gradients can also influences SOM by controlling soil water balance, soil erosion and geologic deposition processes [21]. In line with this a positive correlation between SOM and altitude has been reported by Sims and Nielsen [50], and Tate [51].

The overall high total $\mathrm{N}$ status of soils of the area in general and the variation within sites in particular might be associated to the variablity of soil OM with elevation gradient. However, although top soils may contain several thousand kilograms of nitrogen per hectare, most of which might be locked up in soil organic matter and not directly available to plants [52]. 


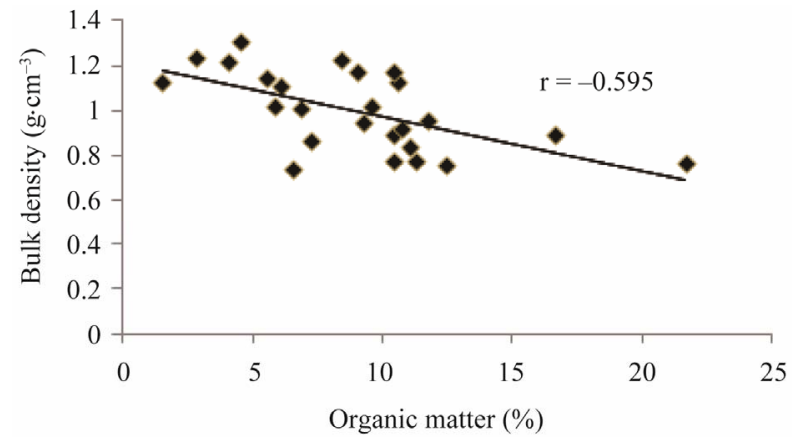

Figure 2. Relationship between soil bulk density and OM.

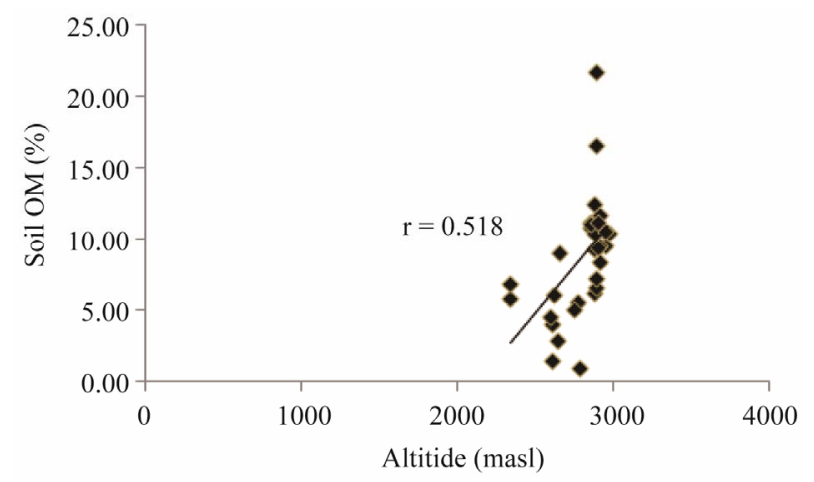

Figure 3. Correlation between soil OM and altitude.

\subsection{Land Use Type Impact on Some Physical and Chemical Properties of Acidic Soils}

\subsubsection{Soil pH}

The average surface soil $\mathrm{pH}$ value of the area was low (Table 2) and ranged from very strongly acidic to slightly acidic as per the $\mathrm{pH}$ rating category suggested by Dekker [39]. It was observed that soil $\mathrm{pH}$ was significantly affected by land use type difference (Table 4). Soils of the forest land were less acidic by 1.16 and 1.12 units than the cultivated and grazing lands, respectively (Table 5).

The lower $\mathrm{pH}$ in soils of the cultivated and grazing lands could be attributed to the removal of basic cations by crop produce and over grazing, respectively. Likewise, it is reported that although acidity is naturally occurring, agricultural practices such as the removal of plant residues carrying organic anions and excess cations from the farm or paddock is likely to accelerate soil acidification $[6,7]$.

The significantly high $\mathrm{pH}$ of soils from the forest land of the area might be attributed to the ameliorating effect of the high accumulation of organic matter at surface. This ameliorating effect of soil OM could be due to the combined effect of the continuous releasing of basic

Table 4. F statistics and probabilities of surface layer $(0-30 \mathrm{~cm}$ depth) soil properties under three different land use types of the Tsegede highlands.

\begin{tabular}{lcc}
\hline Soil property & F-value & P-value \\
\hline Sand & 1.26 & 0.2863 \\
Silt & 3.14 & 0.0631 \\
Clay & 1.25 & 0.3073 \\
Bulk density & 0.92 & 0.4176 \\
pH & 10.82 & 0.0001 \\
Exchangeable acidity & 7.17 & 0.0012 \\
Exchangeable Al & 91.35 & 0.0001 \\
OM & 4.02 & 0.0331 \\
Total N & 5.58 & 0.0110 \\
Available P & 9.79 & 0.0009 \\
\hline
\end{tabular}

Table 5. Soil pH, exchangeable acidity (EA), exchangeable Al (Ex. Al), OM, total $\mathbf{N}$ and available $\mathbf{P}$ (Means \pm SE) contents across three land use types.

\begin{tabular}{|c|c|c|c|}
\hline Soil property & Cultivated land & Grazing land & Forest land \\
\hline $\mathrm{pH}$ & $4.56 \pm 0.05^{\mathrm{b}}$ & $4.60 \pm 0.07^{b}$ & $5.72 \pm 0.07^{\mathrm{a}}$ \\
\hline Exchangeable acidity $\left(\mathrm{cmol}_{\mathrm{C}} \cdot \mathrm{kg}^{-1}\right)$ & $4.64 \pm 0.21^{\mathrm{a}}$ & $3.93 \pm 0.25^{\mathrm{a}}$ & $0.28 \pm 0.21^{\mathrm{b}}$ \\
\hline Exchangeable $\mathrm{Al}\left(\mathrm{cmol}_{\mathrm{C}} \cdot \mathrm{kg}^{-1}\right)$ & $3.81 \pm 0.21^{\mathrm{a}}$ & $3.15 \pm 0.26^{\mathrm{a}}$ & $0.00 \pm 0.26^{\mathrm{b}}$ \\
\hline Bulk density $\left(\mathrm{g} \cdot \mathrm{cm}^{-1}\right)$ & $1.03 \pm 0.05^{\mathrm{a}}$ & $0.93 \pm 0.05^{\mathrm{a}}$ & $1.00 \pm 0.05^{\mathrm{a}}$ \\
\hline Organic matter (\%) & $7.07 \pm 0.80^{\mathrm{b}}$ & $9.51 \pm 0.9^{\mathrm{da}}$ & $10.42 \pm 0.96^{\mathrm{a}}$ \\
\hline Total N (\%) & $0.30 \pm 0.04^{\mathrm{b}}$ & $0.38 \pm 0.04^{\mathrm{ab}}$ & $0.49 \pm 0.04^{\mathrm{a}}$ \\
\hline Available $\mathrm{P}\left(\mathrm{mg} \cdot \mathrm{kg}^{-1}\right)$ & $3.04 \pm 3.692^{\mathrm{b}}$ & $2.93 \pm 4.40^{\mathrm{b}}$ & $26.17 \pm 4.40^{\mathrm{a}}$ \\
\hline
\end{tabular}

Mean values within rows of each soil property followed by the same letter(s) are not significantly different at $\mathrm{P} \leq 0.05$. 
cations from the slow decomposition rate of the accumulated organic matter in that cool humid area, deposition of basic cations at the surface by the relatively deep root forest trees from the subsoil and the specific adsorption of organic anions on hydrous Fe and Al surfaces and the corresponding release of hydroxyl ions. In connection with this, Caixan and Rengel [53] reported that trees and shrubs may play a role in minimizing soil acidification through the development of deep root systems capable of taking up bases such as $\mathrm{Ca}$ and $\mathrm{Mg}$ from deep layers of the soil profile and returning them to the topsoil as leaf litter containing excess basic or alkaline cations.

\subsubsection{Soil Exchangeable Acidity and Exchangeable Al} Mean value of surface soil exchangeable acidity of the area was found to be High (Table 2). Highly significant variation of exchangeable acidity within the land use types was observed (Table 4). It showed significant increment in the grazing and cultivated lands as compared to that of the forest land soils (Table 5). Similarly, exchangeable Al was showed a highly significant variation within land use types (Table 4). It was significantly lower by 3.81 and 3.15 units in the forest land soils than the cultivated and grazing lands, respectively (Table 5).

The high soil exchangeable acidity in the cultivated and grazing lands might be associated to the occurrence of lower soil $\mathrm{pH}$ in both the land use types. It was also showed strong negative correlation $(\mathrm{r}=-0.77)$ with $\mathrm{pH}$ and was much higher in the soils with a $\mathrm{pH}$ less than 5.5. Reports also pointed out that exchangeable acidity is a function of soil $\mathrm{pH}$ composed of compounds such as $\mathrm{Al}(\mathrm{OH})^{2+}$ or $\mathrm{Al}(\mathrm{OH})_{2}^{+}$, and weak organic acid ions held at the colloidal surfaces of the soil $[9,10,54]$.

The significant variation of soil exchangeable $\mathrm{Al}$ within the land use types might be closely related to their soil $\mathrm{pH}$ and exchangeble acidity status differnce. A strong negative relationship was also observed between the overall exchangeable $\mathrm{Al}$ and $\mathrm{pH}$ (Figure 4(a)) and it was mainly observed in soils where there was a $\mathrm{pH}$ of more or less below 5. Likewise, it had also a close correlation with exchangeable acidity (Figure 4(b)). It is generally considered that $\mathrm{Al}$ increases in concentration in soil solution below pH 5.5 [12-14].

\subsubsection{Soil Organic Matter and Total Nitrogen}

It was observed that soil OM was significantly influenced by land use type (Table 4). Although OM contents of the soils in all the land use types were rated as high, soils of the cultivated land was having significantly lower by about 25 and 35 percent than the grazing and forest land soils, respectively (Table 5). Similarly, total $\mathrm{N}$ was also showed significant variation within the the different land use types (Table 4).

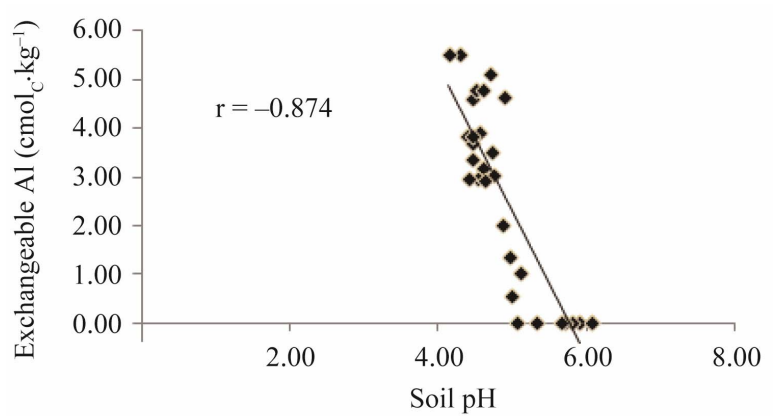

(a)

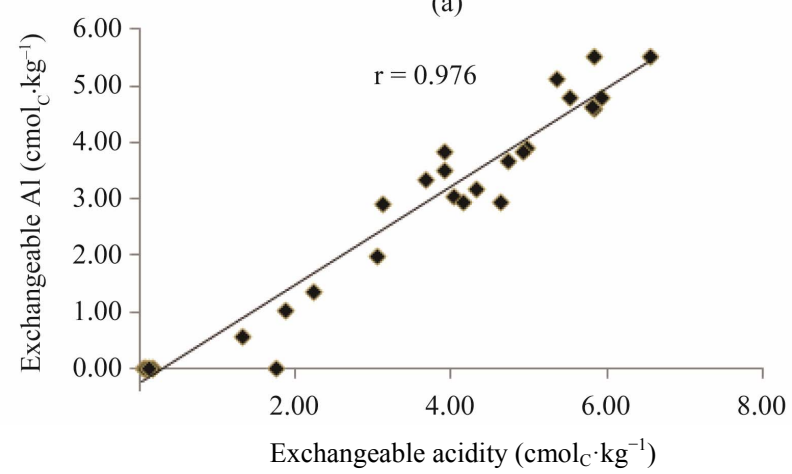

(b)

Figure 4. Correlations of exchangeable $\mathrm{Al}$ with $\mathrm{pH}$ (a) and exchangeable acidity (b).

The relatively lower accumulation of soil OM in the cultivated land might be attributed to the process of cultivation which is nearly always associated with a loss of organic carbon. In line with our report, it is suggested that the low accumulation of $\mathrm{OM}$ in cultivated land sols could be due to 1) the reduction in total organic inputs (litter, crop residues, manure); 2) increased mineralizetion rates of organic matter caused by tillage; 3 ) increased soil temperatures due to exposure of the soil surface and 4) increased wetting-and-drying cycles and the los by soil erosion [55-57].

\subsubsection{Available Phosphorus}

Average available surface soil P status (Bray method) of the area was low (Table 2) as per the classification rate suggested by Beegle and Oravec [58]. It was significantly affected by the land use types (Table 4). In soils of the forst land available soil $\mathrm{P}$ was significantly higher by about $88 \%$ compared to that of cultivated and grazing land soils (Table 5).

The low available $\mathrm{P}$ status in the cultivated and grazing land soils seems to be related mainly to the presence of low $\mathrm{pH}$ and high exchangeable acidity. It showed a highly significant posetive correlation $(\mathrm{r}=0.65)$ with $\mathrm{pH}$ and negative correlation $\left(\mathrm{r}=-0.58^{*}\right)$ with exchangeable acidity. Hence, this soil with high exchangeable acidity can have the acidic cations such as exchangeable Al, H, 
and oxides of $\mathrm{Al}$ and $\mathrm{Fe}$ that could fix the soluble $\mathrm{P}$ in the soil solution. A negative correlation $\left(\mathrm{r}=-0.53^{*}\right)$ was also obserbed between available $\mathrm{P}$ and exchangeable $\mathrm{Al}$. A significant positive relationship $(\mathrm{r}=0.78)$ between $\mathrm{pH}$ and $\mathrm{P}$ fixation as a result of these soluble acidic metal ions was also reported from the study done to determined the phosphorus fixing capacity of some soils of Mauritius [59]. In the other hand, the presence of relatively higher available $\mathrm{P}$ in the forest soil could be attributed to the presence of high $\mathrm{pH}$ and $\mathrm{OM}$ which was having a positive relationship $\left(\mathrm{r}=0.47^{*}\right)$. The specific adsorption of organic anions on hydrous $\mathrm{Fe}$ and $\mathrm{Al}$ surfaces and the corresponding release of hydroxyl ions [60] could increase the $\mathrm{pH}$ and available $\mathrm{P}$ in the soil solution.

\subsection{Soil Acidity Map of Tsegede Highlands}

From the analytical results and GPS readings of the total 108 surface layer $(0-30 \mathrm{~cm}$ depth) composite soil samples of the three sites and land use types of Tsegede highlands, acidity map was developed on the scale of 1:60,000. The map was made to display the different soil acidity categories of the area. Soil acidity or basicity of an area is normally measured by soil $\mathrm{pH}$, concentration of hydronium ion $\left(\mathrm{H}_{3} \mathrm{O}^{+}\right.$or, more commonly, the $\left.\mathrm{H}^{+}\right)$in soil solution. Based on this, acidity categories of Tsegede highlands was found to have $50 \%, 31 \%, 15 \%$, and $4 \%$ of very strong acidic, strongly acidic, moderately acidic and slightly acidic coverage, respectively (Figure 5).

From the map, it can be exhibited that $46 \%, 24 \%$ and $19 \%$ of very strong acidic coverage was in Indamriam, Cheguarudo and Indaslasie sites, respectively. Indamariam had very strong acidity coverage as compared to the other two sites. This shows that elevation in the study area doesn't affect soil $\mathrm{pH}$. This very strong acidic coverage might be developed due to the intensively cultivated and over grazed lands occurred in Indamariam. The presence of relatively intensive cultivation and over grazing lands in the area is due to the presence of large rock outcrop coverage which leads to area limitation. Thus, this intensive cultivation and over grazing activities could most probably aggravate the acidification process of this specific area.

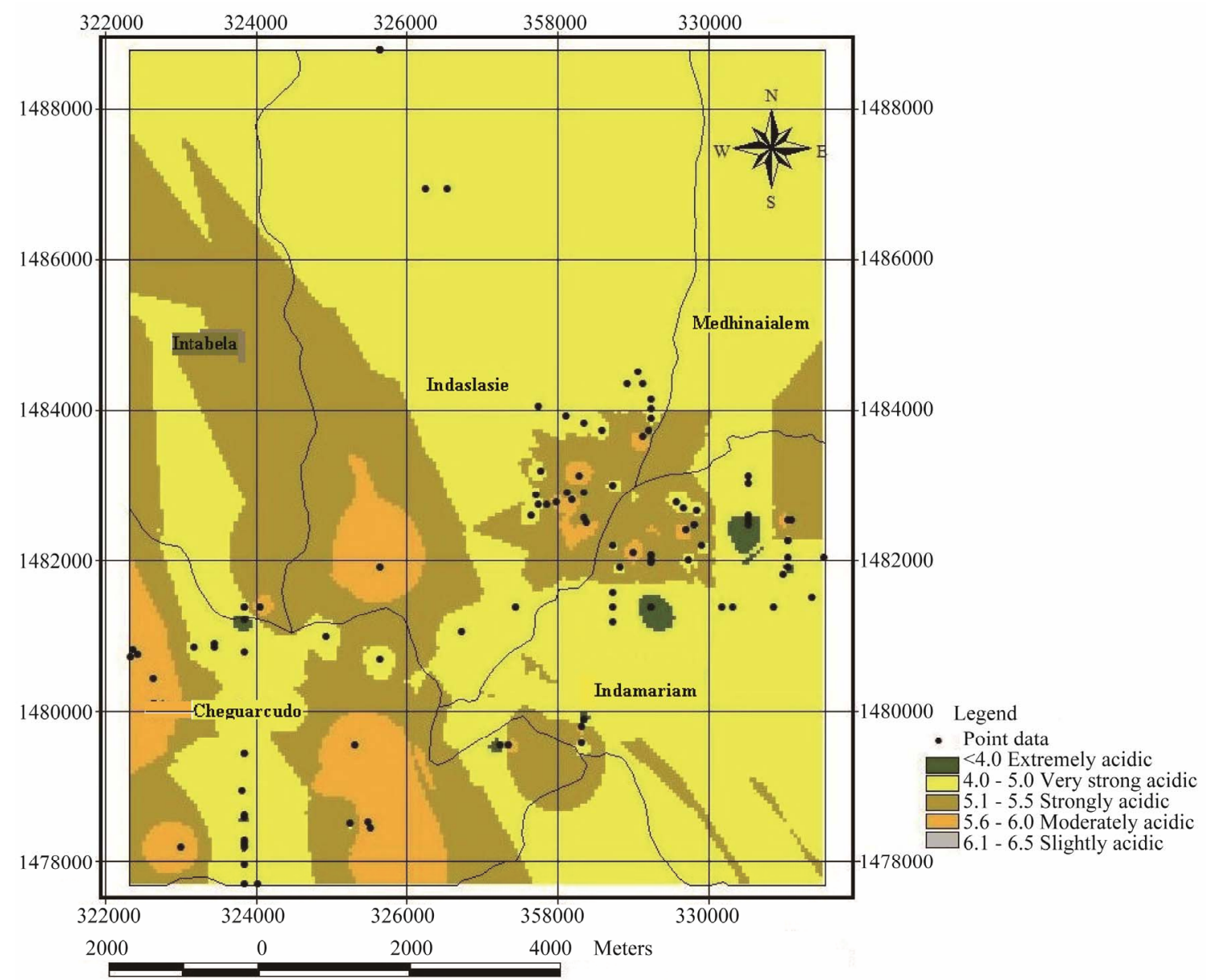

Figure 5. Soil acidity map of Cheguarcudo, Indamariam, Indaslasie and adjacent sites of Tsegede highland. 
The cultivated and grazing land use types were dominated by very strong acidic and strongly acidic soils whereas soils of the forest land were more of strongly acidic and moderately acidic (Figure 6). Soil acidity of the grazing lands was mainly ranged within the very strongly acidic and strongly acidic soils only. The high coverage of strongly acidic soils in these grazing lands most likely indicates the strong impact of intensive overgrazing that might aggravate acidification. In general, it was observed that most of the soils of the cultivated and grazing lands were fall in the very strongly acidic while forest land were dominated by strongly and moderately acidic because of the relatively higher $\mathrm{pH}$ it had.

Such strong and very strong acidity category could indicate the presence of more $\mathrm{Al}$ ion concentration in the soil solution of these cultivated and grazing lands. The release of $\mathrm{Al}$ into the soil solution as a result of proton buffering is suggested to have effects on root growth and nutrient uptake $[61,62]$. Hence, this considerable extent of acidity coverage could affect crop as well as forage growth of the area. Thus, acid soil management strategy options should be developed.

\section{Conclusions}

The study showed that the changes in altitude and land use types had significant impact on the spatial distribution of some physical and chemical properties of acidic soils in the Tsegede highlands of Tigray. Surface layer ( 0 - $30 \mathrm{~cm}$ ) soil of the area showed variability in soil attributes such as bulk density, $\mathrm{OM}$ and total $\mathrm{N}$ as a result of differences in elevation whereas soil $\mathrm{pH}$ did not. The variability in soil OM content among the lower and higher elevation sites was due to the difference in temperature which affects the soil OM decomposition and mineralization which increases with increasing temperature. Thus, the surface soil OM concentration in the area was positively correlated with altitude as temperature and so oxidation loss of OM decrease with increasing altitude.

Soil $\mathrm{pH}$, exchangeable acidity, exchangeable Al, OM, total $\mathrm{N}$ and available phosphorus also exhibited significant variability across the different land use types. The low $\mathrm{pH}$ and high exchangeable acidity and $\mathrm{Al}$ contents in the soils of the area seems mainly associated to leaching of basic cations by the excessive rainfall prevalent in the area and is aggravated by their removal through crop and forage produce.

Generally, it seems that altitude does not have any part in aggravating soil acidity whereas the conversion of forest land in to grazing and cultivated land aggravates soil acidity of the area. Therefore, it is suggested that besides to the usual acid soil management and/or recla-

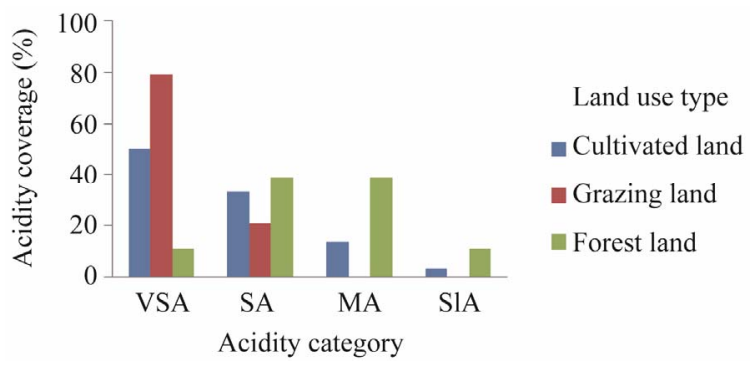

Figure 6. Soil acidity category and its coverage across three land use types of Tsegede highlands. VSA = Very strong acidic; SA = Strongly acidic; MA = Moderately acidic; SLA $=$ Slightly acidic.

mation practices, introducing appropriate land use and management practices are of paramount importance in order to prevent the development and reduce the impact of soil acidity.

\section{Acknowledgements}

This work was supported by grants of the Rural Capacity Building Project of Ethiopia for which it is acknowledged. We also would like to thank the Tigray Agricultural Research Institute for providing us the necessary resource, particularly laboratory facilities and services, required to conduct the study.

\section{REFERENCES}

[1] D. Abdenna, C. W. Negassa and G. Tilahun, "Inventory of Soil Acidity Status in Crop Lands of Central and Western Ethiopia, Utilisation of Diversity in Land Use Systems: Sustainable and Organic Approaches to Meet Human Needs," Witzenhausen, 9-11 October 2007.

[2] B. Taye, "An Overview of Acid Soils Their Management in Ethiopia," The 3rd International Workshop on Water Management (Waterman) Project, Haramaya, 2007, pp. 19-21.

[3] World Bank, "Staff Appraisal Report," National Fertilizer Sector Project, Ethiopia, Report No. 13722-ET, 1995.

[4] H. Wassie and B. Shiferaw, "Mitigation of Soil Acidity and Fertility Decline Challenges for Sustainable Livelihood Improvement: Research Findings from Southern Region of Ethiopia and Its Policy Implications," Awassa Agricultural Research, Awassa, 2009.

[5] P. Lenka, B. Luboš, N. Antonín, R. Marcela and P. VÍT, "Altitude and Forest Type Effects on Soils in the Jizera Mountains Region," Soil \& Water Research, Vol. 2, No. 2, 2007, pp. 35-44.

[6] W. Schumann and S. Glover, "The Acid Soil Action Program for Southern NSW," Proceedings 14th Annual Conference, Queanbeyan, 13-15 July 1999, pp. 55-58.

[7] S. B. Nanthi and J. H. Mike, "Role of Carbon, Nitrogen, and Sulfur Cycles in Soil Acidification," In: Z. Rengel, Ed., Hand Book of Soil Acidity, University of Western 
Australia Perth, Perth, 2003, pp. 42-43.

[8] B. Ulrich, "Nutrient and Acid-Base Budgets of Central European Forest Ecosystems," In: D. L. Godbold and A. Hüttermann, Eds., Effects of Acid Rain on Forest Processes, John Wiley \& Sons, New York, 1994, pp 231-264.

[9] D. Foth Henry, "Fundamentals of Soil Science," 8th Edition, Michigan State University, John Wiley \& Sons, New York, 1990 .

[10] L. B. Hinrich, L. M. Brian and A. O'Connor George, "Soil Chemistry," John Wily \& Sons, Inc., New York, 2001.

[11] H. Asp and D. Berggren, "Phosphate and Calcium Uptake in Beech (Fagus sylvatica L.) in the Presence of Aluminium and Natural Fulvic Acids," Plant Physiology, Vol. 80, No. 2, 1990, pp. 307-314.

[12] H. Matsumoto, "Biochemical Mechanism of the Toxicity of Aluminium and the Sequestration of Aluminium in Plant Cells," In: R. J. Wright, V. C. Baligar and R. P. Murrmann, Eds., Plant-Soil Interactions at Low pH, Kluwer Academic Publishers, Dordrecht, 1991, pp. 825-838. doi:10.1007/978-94-011-3438-5 93

[13] R. L. Parfitt, H. J. Percival and G. Van Der Lee, "Aluminium Species and $\mathrm{pH}$ in Soil Solution under Different Crops," In: R. A. Date, N. J. Grundon, G. E. Rayment and M. E. Probert, Eds., Plant-Soil Interactions at Low pH, Kluwer Academic Publishers, Dordrecht, 1995, pp. 817822. doi:10.1007/978-94-011-0221-6 131

[14] T. B. Kinraide, "Identity of the Rhizotoxic Aluminium Species," In: R. A. Date, N. J. Grundon, G. E. Rayment and M. E. Probert, Eds., Plant-Soil Interactions at Low pH, Kluwer Academic Publishers, Dordrecht, 1995, pp. 717-728.

[15] R. D. Bardgett, A. C. Jones, D. L. Jones, S. J. Kemmitt, R. Cook and P. Hobbs, "Soil Microbial Community Patterns Related to the History and Intensity of Grazing in SubMontane Ecosystems," Soil Biology and Biochemistry, Vol. 33, No. 12-13, 2001, pp. 1653-1664.

[16] E. Bååth and T. H. Anderson, "Comparison of Soil Fungal/Bacterial Ratios in a $\mathrm{pH}$ Gradient Using Physiological and PLFA-Based Techniques," Soil Biology and Biochemistry, Vol. 35, No. 7, 2003, pp. 955-963. doi:10.1016/S0038-0717(03)00154-8

[17] A. R. Townsend, P. M. Vitousek, S. E. Trumbore, "Soil Organic Matter Dynamics along Gradients in Temperature and Land Use on the Island of Hawaii," Ecology, Vol. 76, No. 3, 1995, pp. 721-733. doi:10.2307/1939339

[18] S. E. Trumbore, P. M. Vitousek and R. R. Amundson, "Rapid Exchange between Soil Carbon and Atmospheric Carbon Dioxide Driven by Temperature Change," Science, Vol. 272, No. 5260, 1996, pp. 393-396. doi:10.1126/science. 272.5260 .393

[19] C. T. Garten, W. M. Post, P. J. Hanson and L. W. Cooper, "Forest Soil Carbon Inventories and Dynamics Along an Elevation Gradient in the Southern Appalachian Mountains," Biogeochemistry, Vol. 45, No. 2, 1999, pp. 115-145. doi:10.1007/BF01106778

[20] M. Lemenih and F. Itanna, "Soil Carbon Stocks and
Turnovers in Various Vegetation Type and Arable Lands Along an Elevation Gradient in Southern Ethiopia," Geoderma, Vol. 123, No. 1-2, 2004, pp. 177-188.

[21] Z. X. Tan, R. Lal, N. E. Smeck and F. G. Calhoun, "Relationships between Surface Soil Organic Carbon Pool and Site Variables," Geoderma, Vol. 121, No. 3-4, 2004, pp. 185-187.

[22] FAO, "Highland Reclamation Study," Final Report, Vol. 1-2. FAOI, Rome, 1986.

[23] H. Hurni, "Climate, Soil, and Water: Degradation and Concervation of the Resources in the Ethiopian Highlands," Mountain Research and Development, Vol. 8, No. 2-3, 1988, pp. 123-130. doi:10.2307/3673438

[24] EFAP (Ethiopian Forestry Action Program), "Ethiopian Forestry Action Program: The Challenge for Development," Ministry of Natural Resources Development and Environmental Protection, Addis Ababa, Vol. 2, 1994.

[25] K. Tekle, "Land Degradation Problems and their Implications for Food Shortage in South Wello, Ethiopia," Environmental Management, Vol. 23, No. 4, 1999, pp. 419427.

[26] Tigray Agricultural Research Institute (TARI), "Progress Report," Mekele, 2008.

[27] MoA, "Agroecological Zones of Ethiopia," Natural Resources Management and Regulatory Department, Addis Ababa, 1998.

[28] Tsegede Water Resource Development Office, "Quarter Year Report," Ketema Nugus, 2011.

[29] FAO, "Soils Map of the World 1:5,000,000," FAO/ UNESCO, Rome, 1981.

[30] Ethiopian Institute of Geological Survey, "Geological Survey for Adi Ramet at Scale of 1:250, 000," Ministry of Mine and Energy and Ethiopian Institute Mapping Agency, Adis Ababa, 1982.

[31] P. R. Hesse, "A Text Book of Soil Chemistry Analysis," John Murray Ltd., London, 1971, pp. 120-309.

[32] P. R. Day, "Particle Fraction and Particle Size Analysis," In: C. A. Black, et al., Eds., Methods of soil analysis, Part 2, American Society of Agronomy, Madison, 1965, pp. 545-567.

[33] V. C. Jamison, H. H. Weaver and I. F. Reed, "A Hammer-Driven Soil Core Sampler," Soil Science, Vol. 69, No. 6, 1950, pp. 487-496.

[34] M. Peech, "Hydrogen Ion Activity," In: C. A. Black, et al., Eds., Methods of soil analysis, Part 2, American Society of Agronomy, Madison, 1965, pp. 914-926.

[35] M. E. Summer, "Determination of Exchangeable Acidity and Exchangeable Al Using $1 \mathrm{~N} \mathrm{KCl,"} \mathrm{In} \mathrm{:} \mathrm{S.} \mathrm{J.} \mathrm{Donohue,}$ Ed., Reference Soil and Media Diagnostic Procedures for the Southern Region of the United States, Southern Cooperative Series Bulletin Number 374, Virginia Agricultural Experiment Station, VPI \& SU, Blacksburg, 1992, pp. 41-42.

[36] M. Pansu, J. Gautheyrou and J. Y. Loyer, "Soil Analysis -Sampling Instrumentation and Quality Control," Balkema, Lisse, Abingdon, Exton, Tokyo, 2001, p. 489. 
[37] A. Walkley and C. A. Black, "An Examination of Degtjareff Method for Determining Soil Organic Matter and Proposed Modification of the Proposed Modification of the Chromic Acid Titration Method," Soil Science, Vol. 37, No. 1, 1934, pp. 29-38.

[38] J. M. Bremner, "Total Nitrogen," In: C. A. Black, et al., Eds., Methods of Soil Analysis, Part 2, American Society of Agronomy, Madison, 1965, pp. 1149-1178.

[39] R. H. Bray and L. T. Kurtz, "Determination of Total, Organic and Available Forms of Phosphorus in Soils," Soil Science, Vol. 59, No. 1, 1945, pp. 39-45.

[40] SAS (Statistical Analysis System), "SAS Version 9.1.3," SAS Institute Inc., Cary, 2002.

[41] M. Dekker, "Handbook of Agriculture," New York, 1999.

[42] N. C. Brady, and R. R. Weil, "The Nature and Properties of Soil," Simon \& Schuster, Upper Saddle River, 1999.

[43] K. Sanjay, K. Munesh and A. S. Mehraj, "Effect of Altitudes on Soil and Vegetation Characterstics of Pinus roxburghii Forest in Garhwal Himalaya," Journal of Advanced Laboratory Research in Biology, Vol. 1, 2010.

[44] J. B. Jones, "Agronomic Handbook: Management of Crops, Soils, and Their Fertility," CRC Press, Boca Raton, 2002. doi:10.1201/9781420041507

[45] J. R. Landon, "A Handbook for Soil Survey and Agricultural Land Evaluation in the Tropics and Subtropics," Booker Tropical Soil Manual, Longman Group Ltd., Harlow, 1984.

[46] V. C. Cole, K. Paustian, E. T. Elliott, A. K. Metherell, D. S. Ojima and W. J. Parton, "Analysis of Agroecosystem Carbon Pools," Water Air and Soil Pollution, Vol. 70, No. 1-4, 1993, pp. 357-371.

[47] Å. Frostegård, E. Bååth and A. Tunlid, "Shifts in the Structure of Soil Microbial Communities in Limed Forest as Revealed by Phospholipid Fatty Acid Analysis," Soil Biology and Biochemistry, Vol. 25, No. 6, 1993, pp. 723-730.

[48] E. V. Blagodatskaya and T. H. Anderson, "Interactive Effects of $\mathrm{pH}$ and Substrate Quality on the Fungal-toBacterial Ratio and $\mathrm{qCO}_{2}$ of Microbial Communities in Forest soils," Soil Biology and Biochemistry, Vol. 30, No. 10-11, 1998, pp. 1269-1274.

[49] T. Arao, "In Situ Detection of Changes in Soil Bacterial and Fungal Activities by Measuring ${ }^{13} \mathrm{C}$ Incorporation into Soil Phospholipid Fatty Acids from ${ }^{13} \mathrm{C}$ Acetate," Soil Biology and Biochemistry, Vol. 31, No. 7, 1999, pp. 1015-1020.

[50] Z. R. Sims and G. A. Nielsen, "Organic Carbon in Montana Soils as Related to Clay Content and Climate," Soil Science Society of America Journal, Vol. 50, No. 5, 1986, pp. 1269-1271.

[51] K. R. Tate, "Assessment, Based on a Climosequence of
Soil in Tussock Grasslands, of Soil Carbon Storage and Release in Response to Global Warming," Journal of Soil Science, Vol. 43, No. 4, 1992, pp. 697-707.

[52] G. Schroth, J. Lehmann and E. Barrios, "Soil Nutrient Availability and Acidity," In: G. Schroth and F. L. Sinclair, Eds., Trees, Crops and Soil Fertility, CAB International, Wallingford, 2003, pp. $104-106$.

[53] T. Caixan and R. Zdenko, "Role of Plant Cation/Anion Uptake Ratio in Soil Acidification," In: Z. Rengel, Eds., Hand Book of Soil Acidity, University of Western Australia Perth, Perth, 2003, pp. 70-77.

[54] E. Matzher, M. Pijpers, W. Holland and B. Mandersheid, "Aluminum in Soil Solutions of Forest Soils: Influence of Water Flow and Soil Aluminum Pools," Soil Science Society of America Journal, Vol. 62, No. 2, 1998, pp. 445454.

[55] E. G. Gregorich, K. J. Greer, D. W. Anderson and B. C. Liang, "Carbon Distribution and Losses: Erosion and Deposition Effects," Soil and Tillage Research, Vol. 47, No. 3-4, 1998, pp. 291-302.

[56] C. A. Palm, C. N. Gachengo, R. J. Delve, G. Cadisch and K. E. Giller, "Organic Inputs for Soil Fertility Management in Tropical Agroecosystems: Application of an Organic Resource Database," Agriculture, Ecosystems and Environment, Vol. 83, No. 1-2, 2001, pp. 27-42.

[57] B. Chroth, Vanlauwe and J. Lehmann, "Soil Organic Matter," In: G. Schroth and F. L. Sinclair, Eds., Tres, Crops and Soil Fertility, CAB International, Wallingford, 2003, pp. 78-79.

[58] D. B. Beegle and T. C. Oravec, "Comparison of Field Calibrations for Mehlich-III P and K with Bray P1 and Ammonium Acetate $\mathrm{K}$ for Corn," Communications in Soil Science and Plant Analysis, Vol. 21, No. 13-16, 1990, pp. 1025-1036.

[59] B. Lalljee, "Phosphorous Fixation as Influenced by Soil Characteristics of Some Mauritian Soils," Food and Agricultural Research Council, University of Mauritius, Réduit, 1997.

[60] N. V. Hue, "Correcting Soil Acidity of a Highly Weathered Ultisol with Chicken Manure and Sewage Sludge," Communications in Soil Science and Plant Analysis, Vol. 23, No. 3-4, 1992, pp. 241-264.

[61] D. B. Ulrich Murach, "Destabilization of Forest Ecosystems by Acid Deposition," GeoJournal, Vol. 17, No. 2, 1988, pp. 253-260.

[62] C. S. Cronan and D. F. Grigal, "Use of Calcium/Aluminum Ratios as Indicators of Stress in Forest Ecosystems," Journal of Environmental Quality, Vol. 24, No. 2, 1995, pp. 209-226. 